\title{
Performance of Rabi Sorghum as Influenced by Preceding Legumes, Nitrogen Levels and Irrigation Schedules
}

\author{
R.V.T. Balazzii Naaiik*, J.S. Mishra and A. Madhavi \\ Department of Agronomy, Regional Sugarcane and Rice Research Station, Rudrur, \\ Nizamabad, Professor Jayashankar Telangana State Agricultural University, \\ Telangana, India \\ *Corresponding author
}

\section{A B S T R A C T}

A field experiment was conducted for two consecutive years during 2012 and 2013 at Indian Institute of Millet Research, Rajendranagar, Hyderabad. The experiment was

\begin{tabular}{|c|}
\hline Keywords \\
\hline $\begin{array}{l}\text { Sorghum, Legumes, } \\
\text { Nitrogen Levels, } \\
\text { Irrigation Schedules }\end{array}$ \\
\hline Article Info \\
\hline $\begin{array}{l}\text { Accepted: } \\
\text { 26 October } 2018 \\
\text { Available Online: } \\
\text { 10 December } 2018\end{array}$ \\
\hline
\end{tabular}
carried out in strip split plot design with three replications. Four strips of treatments including dhaincha, greengram and cowpea raised as preceding kharif legumes along with fallow are taken as main plot treatments. During rabi, sorghum was grown in split plot design taking strips of kharif crops as main plots, four irrigation schedules assigned to sub plots and four nitrogen levels viz., 0, 30, 60 and $90 \mathrm{~kg} \mathrm{ha}^{-1}$ to sub sub plots. The plants attained maximum height $(225.6 \mathrm{~cm}$ and $217.2 \mathrm{~cm})$, highest dry matter production $(8197$ and $9151 \mathrm{~kg} \mathrm{ha}^{-1}$ ), grains per panicle (1160 and 1247) and ear head weight (46.3 and 47.1 g) with in situ incorporation of dhaincha during 2012 and 2013 followed by irrigation at panicle initiation, boot leaf stage, anthesis and milk stage at harvest, and a high dose of 90 $\mathrm{kg} \mathrm{ha}{ }^{-1} \mathrm{~N}$ significantly increased the growth and yield components. The in situ incorporation of dhaincha was 2511 and $3024 \mathrm{~kg} \mathrm{ha}^{-1}$ was during both years. Irrigation at 4 critical phases recorded $2528 \mathrm{~kg} \mathrm{ha}^{-1}$ during 2012 and $3047 \mathrm{~kg} \mathrm{ha}^{-1}$ during 2013. Further, $2686 \mathrm{~kg} \mathrm{ha}^{-1}$ and $3269 \mathrm{~kg} \mathrm{ha}^{-1}$ during 2012 and 2013, respectively' by the application of $\mathrm{N}$ $90 \mathrm{~kg} \mathrm{ha}^{-1}$.

\section{Introduction}

Sorghum, the fifth important cereal food crop after corn, rice, wheat and barley on the globe (Fageria et al., 2014), is considered as the king of millets and extensively grown both for grain as food, animal feed and stalks as animal fodder. It is the major cereal of rainfed agriculture in the semiarid tropics. Organic manures and crop residues have been proved to be viable components of nitrogen management, which can supplement and successfully replace costly fertilizer nitrogen. The practice of residue incorporation after the harvest is feasible and economical, where a period of 30 days is available before planting of maize and the practice can contribute to about 50 to $60 \mathrm{~kg} \mathrm{~N}$ ha $^{-1}$ (Kulakarni and Pandey, 1988). As the crop is raised mostly under rainfed condition with the help of stored moisture, the moisture deficit, especially during later stages of crop growth poses a serious threat to the crop consequently the 
yield levels of rabi sorghum are very low. Besides water, fertilizer is also one of the important basic inputs for realizing yield potential of fertilizer responsive high yielding varieties have further increased the demand for important crop nutrients. However, the low yield potential of rabi sorghum is attributed mainly due to moisture stress cycles, during the flowering and grain formation stages (Mohiuddin and Yaseen, 1973). Application of one or two supplemental irrigations during such stress cycles gives a manifold increase in the grain yield of rabi sorghum (Patil et al., 1981, Ramshe et al., 1985 and Bhoi and Jadhav, 1986). In the light of above, the present investigation was planned and carried out.

\section{Materials and Methods}

A field experiment on "performance of rabi sorghum as influenced by preceding legumes, nitrogen levels and irrigation schedules" was conducted for two consecutive years during the years 2012 and 2013 at the Indian Institute of Millet Research - ICAR, Rajendranagar, Hyderabad. The soil was clay loam in texture. The $\mathrm{pH}$ was 7.7 and EC was $0.38 \mathrm{dSm}^{-1}$. The organic carbon was $0.23 \%$ and the available $\mathrm{N}$ was $162 \mathrm{~kg} \mathrm{ha}^{-1}$. Their status was low. However, the soil fertility was medium in available phosphorus with $29.1 \mathrm{~kg}_{2} \mathrm{O}_{5} \mathrm{ha}^{-1}$ and available potassium with $282.8 \mathrm{~kg} \mathrm{~K}_{2} \mathrm{O}$ $\mathrm{ha}^{-1}$. The layout of the design was strip-split plot with 3 replications. There were four strips of legumes in kharif viz., dhaincha, green gram, cowpea and fallow. Sorghum was sown in split plot layout in each strip in the following rabi with four main plots of irrigation and four sub-sub plots of nitrogen levels. Dhaincha was grown till the commencement of flowering and then incorporated in situ. The greengram pods were picked for grain and haulms were then turned down into the soil. The cowpea foliage was harvested for fodder and the stubbles turned down into the soil for decomposition. The irrigations were scheduled at critical stages viz., panicle initiation, boot leaf stages anthesis and milk stage of grain sorghum. The levels of nitrogen were $0,30,60$ and $90 \mathrm{~kg}$ $\mathrm{ha}^{-1}$. The test varieties of dhaincha as green manure, greengram for seed and cowpea for fodder were Sesbania cannabina, LGG-407 and EC - 4216 respectively, while the test variety of sorghum was SPV-2048 (Phule Suchitra).

\section{Results and Discussion}

\section{Effect on growth characters}

The rabi sorghum crop influenced by different crop residues, irrigation at critical stages and nitrogen management practices to sorghum noticeably altered the growth parameters (Table 1). The decomposing residue of dhaincha improved the vegetative growth of sorghum in the rabi season. There was a significant increase in the plant height, LAI and drymatter production of the crop from seedling stage to maturity. The plants attained maximum height to in situ incorporation of dhaincha followed by irrigation at panicle initiation, boot leaf stage, anthesis and milk stage at harvest, there was a significant increase in the plant height due to successive increase in the number of irrigations at the critical phases and a high dose of $90 \mathrm{~kg} \mathrm{ha}^{-1} \mathrm{~N}$. This response was consistent during both 2012 and 2013 years. The in situ incorporation of dhaincha significantly increased the dry matter $8197 \mathrm{~kg} \mathrm{ha}^{-1}$ during 2012 and $9151 \mathrm{~kg} \mathrm{ha}^{-1}$ at harvest, respectively. Dhaincha harvested at the beginning of flowering was succulent with high moisture content, maximum nutrient accumulation in the foliage and expected optimum $\mathrm{C}$ : $\mathrm{N}$ ratio of about 25 . This was ideal for early decomposition. The haulms of greengram were less succulent and more lignified because of their incorporation late at maturity when the pods were harvested. The 
stubbles of cowpea added least biomass to the soil. Confirming the positive role of residual effect of legumes, Mahadkar and Saraf (1988) recorded significant improvement in the dry matter production of sorghum by the incorporation of blackgram haulms in the preceding season. Kambale (1983) reported that irrigation at grand growth stage increased the plant height, number of leaves, leaf area index and dry matter of the crop. Refay (1989) reported that the water stress reduced the ear head exertion, ear head length, plant height and dry weight. Mastronelli et al., (1995) reported that the water stress at booting stage remarkably reduced the dry matter and yield of sorghum.

\section{Effect on yield components}

Sorghum preceded by dhaincha developed more number of grains per panicle and weight of the ear head while the panicle length and 1000 grain weight did not change significantly (Table 2). The number of grains per panicle was significantly influenced by the residual effect of green mass incorporation of legumes in the preceding kharif season. The green manure of dhaincha was most effective among others.

Maximum number of 1160 and 1247 grains were produced per panicle in 2012 and 2013 due to the beneficial carry over effects of this legume. Significantly less number of 1037 and 1164 grains per panicle were recorded in the fallow - sorghum. Sorghum grown in the fallow land was less responsive to irrigations. It produced 969 and 1132 grains per panicle by irrigating the crop only at panicle initiation stage in 2012 and 2013. Additional number of 144 and 61 grains per panicle were produced during the corresponding years by irrigating the crop at 4 critical stages. The interaction effect of sorghum grown after the incorporation of cowpea stubbles and irrigated at panicle initiation produced 983 and 1149 grains per panicle in the corresponding years. Sorghum utilized the water more efficiently than in fallow at high levels of irrigation. Hence, significantly more number of additional 171 and 118 grain per panicle were obtained during the two years by irrigating the crop at 4 critical stages preceding cowpea. The ear head weight of sorghum grown in fallow and irrigated at the panicle initiation stage increased from $42.4 \mathrm{~g}$ in 2012 and $43.2 \mathrm{~g}$ in 2013 to 47.2 and $44.0 \mathrm{~g}$ by irrigating the crop at 4 critical stages. The gain in weight due to increase in irrigation was thus $4.8 \mathrm{~g}$ in the first year and $0.8 \mathrm{~g}$ in the second year. Henadez et al., (1992) reported that the ear head weight decreased due to moisture stress at all the critical stages, except when stressed at physiological maturity. Nitrogen improved the yield components remarkably. A low dose of $30 \mathrm{~kg} \mathrm{ha}{ }^{-1} \mathrm{~N}$ increased the panicle length, grains per panicle, 1000 grain weight and the ear head weight both in 2012 and 2013. These components showed further improvement to high level of nitrogen and the maximum response was at $90 \mathrm{~kg} \mathrm{ha}^{-1} \mathrm{~N}$.

\section{Effect on grain and stover yield}

Maximum grain yield of 2528 and $3047 \mathrm{~kg}$ ha ${ }^{1}$ was obtained by irrigating the crop at panicle initiation, boot leaf, anthesis and milking stage of grain during the two years (Table 3). Sorghum irrigated at the panicle initiation stage produced 2338 and $2870 \mathrm{~kg}$ grain $\mathrm{ha}^{-1}$ during 2012 and 2013 respectively. Irrigation at panicle initiation and boot leaf stage yielded significantly more quantity of 2413 and 2929 $\mathrm{kg}$ grain ha- ${ }^{-1}$. The production increased further to 2477 and $2997 \mathrm{~kg} \mathrm{ha}^{-1}$ during the corresponding years by giving 3 irrigations at panicle initiation, boot leaf and anthesis stage. Mishra et al., (2011) also reported that green manure of dhaincha increased the production of sorghum compared to the yield from fallow-sorghum. 
Table.1 Sorghum growth parameters as influenced by irrigation schedules and levels of nitrogen preceded by kharif legumes at harvest

\begin{tabular}{|c|c|c|c|c|c|c|}
\hline \multirow[t]{2}{*}{ Treatment } & \multicolumn{2}{|c|}{$\begin{array}{l}\text { Plant height } \\
(\mathrm{cm})\end{array}$} & \multicolumn{2}{|c|}{ LAI } & \multicolumn{2}{|c|}{$\begin{array}{c}\text { Dry matter } \\
\text { production } \\
\left(\mathrm{kg} \mathrm{ha}^{-1}\right)\end{array}$} \\
\hline & 2012 & 2013 & 2012 & 2013 & 2012 & 2013 \\
\hline \multicolumn{7}{|l|}{ Preceding legumes in kharif } \\
\hline$C_{1}$ : Sorghum preceded by Dhaincha & 225.6 & 217.2 & 2.1 & 2.3 & 8197 & 9151 \\
\hline $\begin{array}{l}\mathrm{C}_{2}: \quad \text { Sorghum } \\
\text { Greengram for seed }\end{array}$ & 221.5 & 217.3 & 2.0 & 2.1 & 7933 & 9005 \\
\hline $\begin{array}{l}\mathrm{C}_{3}: \text { Sorghum preceded by Cowpea } \\
\text { for fodder }\end{array}$ & 220.6 & 213.3 & 1.3 & 1.6 & 7830 & 8946 \\
\hline $\mathrm{C}_{4}$ : Sorghum preceded by Fallow & 218.5 & 208.3 & 1.3 & 1.4 & 7776 & 8949 \\
\hline $\mathbf{S E m} \pm$ & 1.34 & 1.98 & 0.21 & 0.14 & 76.9 & 68.2 \\
\hline CD at $5 \%$ & 4.6 & 6.8 & NS & 0.5 & 266 & 236 \\
\hline \multicolumn{7}{|l|}{ Irrigation schedules } \\
\hline $\mathrm{I}_{1}$ : Panicle initiation & 210.4 & 201.1 & 1.5 & 1.9 & 7649 & 8700 \\
\hline $\mathrm{I}_{2}:$ PI and booting & 218.1 & 209.9 & 1.6 & 1.9 & 7832 & 8882 \\
\hline$I_{3}:$ PI, booting and anthesis & 225.3 & 217.5 & 1.8 & 1.8 & 8047 & 9138 \\
\hline $\begin{array}{l}\text { I } 4 \text { : PI, booting, anthesis and milk } \\
\text { stage }\end{array}$ & 232.5 & 227.6 & 1.7 & 1.7 & 8209 & 9333 \\
\hline S Em \pm & 1.27 & 1.70 & 0.07 & 0.07 & 31.8 & 13.5 \\
\hline CD at $5 \%$ & 4.5 & 5.8 & NS & NS & 110 & 47 \\
\hline \multicolumn{7}{|l|}{ Nitrogen $\left(\mathrm{kg} \mathrm{ha}^{-1}\right)$} \\
\hline $\mathrm{N}_{1}$ : No Nitrogen & 199.6 & 190.1 & 1.5 & 1.7 & 6902 & 7777 \\
\hline $\mathrm{N}_{2}: 30$ & 220.6 & 210.6 & 1.6 & 1.8 & 7685 & 8719 \\
\hline$N_{3}: 60$ & 230.1 & 222.5 & 1.8 & 1.9 & 8358 & 9560 \\
\hline $\mathbf{N}_{4}: 90$ & 235.9 & 232.8 & 1.8 & 2.0 & 8790 & 9995 \\
\hline $\mathrm{SEm} \pm$ & 4.95 & 4.60 & 0.28 & 0.07 & 223.0 & 220.9 \\
\hline CD at $5 \%$ & 13.8 & 13.0 & NS & NS & 625 & 619 \\
\hline \multicolumn{7}{|l|}{ Interaction } \\
\hline \multicolumn{7}{|l|}{ Kharif legumes $\times$ Irrigation } \\
\hline S Em \pm & 3.32 & 5.16 & 0.42 & 0.35 & 298.7 & 239.0 \\
\hline CD at $5 \%$ & NS & NS & NS & NS & NS & NS \\
\hline \multicolumn{7}{|l|}{ Kharif legumes $\times$ Nitrogen } \\
\hline S Em \pm & 17.26 & 16.48 & 0.14 & 0.14 & 787.5 & 777.4 \\
\hline CD at $5 \%$ & NS & NS & NS & NS & NS & NS \\
\hline \multicolumn{7}{|l|}{ Irrigation $\times$ Nitrogen } \\
\hline S Em \pm & 17.26 & 16.41 & 0.14 & 0.14 & 775.0 & 765.9 \\
\hline CD at $5 \%$ & NS & NS & NS & NS & NS & NS \\
\hline \multicolumn{7}{|l|}{ Kharif legumes $\times$ Irrigation $\times$ Nitrogen } \\
\hline S Em \pm & 4.95 & 4.60 & 0.28 & 0.42 & 223.0 & 220.9 \\
\hline CD at $5 \%$ & NS & NS & NS & NS & NS & NS \\
\hline
\end{tabular}


Table.2 Sorghum yield components as influenced by irrigation schedules and levels of nitrogen preceded by kharif legumes

\begin{tabular}{|c|c|c|c|c|c|c|c|c|}
\hline \multirow[t]{2}{*}{ Treatment } & \multicolumn{2}{|c|}{$\begin{array}{c}\text { Panicle } \\
\text { Length }(\mathrm{cm})\end{array}$} & \multicolumn{2}{|c|}{$\begin{array}{c}\text { Grains } \\
\text { panicle }^{-1}\end{array}$} & \multicolumn{2}{|c|}{$\begin{array}{l}1000 \text { grain } \\
\text { weight (g) }\end{array}$} & \multicolumn{2}{|c|}{$\begin{array}{c}\text { Earhead } \\
\text { Weight (g) }\end{array}$} \\
\hline & 2012 & 2013 & 2012 & 2013 & 2012 & 2013 & 2012 & 2013 \\
\hline \multicolumn{9}{|l|}{ Preceding legumes in kharif } \\
\hline $\begin{array}{l}\mathrm{C}_{1}: \begin{array}{l}\text { Sorghum } \\
\text { Dhaincha }\end{array} \\
\end{array}$ & 16.1 & 18.2 & 160 & 1247 & 6.0 & 5.9 & 16.3 & 47.1 \\
\hline $\begin{array}{l}\mathrm{C}_{2}: \text { Sorghum preceded by } \\
\text { Greengram for seed }\end{array}$ & 16.0 & 7.8 & 1126 & 1206 & 25.9 & 5.8 & 44.2 & 45.9 \\
\hline $\begin{array}{l}C_{3}: \text { Sorghum preceded by } \\
\text { Cowpea for fodder }\end{array}$ & 15.6 & 18.5 & 1073 & 1201 & 26.0 & 26.1 & 43.6 & 46.4 \\
\hline $\mathrm{C}_{4}$ : Sorghum preceded by Fallow & 16.1 & 17.9 & 1037 & 1164 & 26.3 & 25.6 & 44.6 & 44.7 \\
\hline S En & 0.07 & .07 & 4.24 & 4.24 & 0.21 & .71 & 0.07 & 0.14 \\
\hline CD at $5 \%$ & 0.2 & 2 & 14 & 15 & NS & NS & 0.2 & 0.6 \\
\hline \multicolumn{9}{|l|}{ Irrigation schedules } \\
\hline$I_{1}:$ Panicle in & 14.6 & 16.6 & 1030 & 1152 & 24.5 & 24.4 & 41.6 & 44.1 \\
\hline$\overline{I_{2}: P I ~ a n d ~} 1$ & 15.5 & 17.6 & 1078 & 1189 & 25.6 & 25.3 & 44.0 & 45.4 \\
\hline g and anthesis & 16.6 & 18.7 & 1123 & 1217 & 26.5 & 26.5 & 44.9 & 46.7 \\
\hline $\begin{array}{l}\mathrm{I}_{4}: \mathrm{PI} \text {, boot, anthesis and milk } \\
\text { stage }\end{array}$ & 17.2 & 19.5 & 1165 & 1259 & 27.6 & 27.2 & 48.2 & 47.9 \\
\hline$S \operatorname{Em} \pm$ & 0.07 & 0.07 & 3.54 & 4.24 & 0.21 & 0.71 & 0.07 & 0.14 \\
\hline CD at $5 \%$ & 0.2 & 0.2 & 13 & 13 & 0.7 & 2.4 & 0.2 & 0.5 \\
\hline \multicolumn{9}{|l|}{ Nitrogen $\left(\mathrm{kg} \mathrm{ha}^{-1}\right)$} \\
\hline $\mathrm{N}_{1}$ : No Nitrogen & 13.7 & 15.9 & 906 & 1055 & 22.9 & 22.8 & 39.4 & 39.3 \\
\hline $\mathbf{N}_{2}: 30$ & 15.2 & 17.5 & 1059 & 1156 & 25.0 & 25.1 & 43.3 & 44.3 \\
\hline $\mathrm{N}_{3}: 60$ & 16.7 & 18.7 & 1171 & 1259 & 27.2 & 27.0 & 45.7 & 48.4 \\
\hline $\mathbf{N}_{4}: 90$ & 18.2 & 20.3 & 1261 & 1348 & 29.1 & 28.5 & 50.4 & 52.1 \\
\hline S Em \pm & 0.35 & 0.42 & 26.17 & 26.87 & 0.64 & 1.49 & 0.99 & 0.99 \\
\hline CD at $5 \%$ & 1.3 & 1.4 & 91 & 93 & 1.8 & 4.1 & 3.4 & 3.5 \\
\hline \multicolumn{9}{|l|}{ Interaction } \\
\hline \multicolumn{9}{|l|}{ Kharif legumes $\times$ Irrigation } \\
\hline S Em \pm & 0.14 & 0.21 & 12.02 & 12.02 & 0.21 & 0.28 & 0.14 & 0.78 \\
\hline CD at $5 \%$ & NS & $\mathrm{N}$ & 41 & 42 & NS & NS & 0.4 & 2.7 \\
\hline \multicolumn{9}{|l|}{ Kharif legumes $\times$ Nitroge } \\
\hline S Em & 1.34 & 1. & 91.94 & 93.35 & 2.62 & 2.76 & 3.39 & 3.54 \\
\hline CD at $5 \%$ & NS & & NTS & & NS & NS & NS & NO \\
\hline \multicolumn{9}{|l|}{ Irrigation $\times$ Nitrogen } \\
\hline S Em & 1.34 & 1.41 & 91.23 & 93.35 & 2.62 & 2.90 & 3.39 & 3.54 \\
\hline CD at $5 \%$ & NS & 0 & NS & NS & NS & NS & NS & NS \\
\hline \multicolumn{9}{|c|}{ Kharif legumes $\times$ Irrigation $\times$ Nitrogen } \\
\hline S Em $=$ & 0.35 & 0.42 & 26.17 & 26.87 & 0.78 & 0.78 & 0.99 & 0.99 \\
\hline CD at $5 \%$ & NS & NS & NS & NS & NS & NS & NS & NS \\
\hline
\end{tabular}


Table.3 Grain and Stover yield $\left(\mathrm{kg} \mathrm{ha}^{-1}\right)$ of sorghum as influenced by irrigation schedules and levels of nitrogen preceded by kharif legumes

\begin{tabular}{|c|c|c|c|c|}
\hline \multirow[t]{2}{*}{ Treatment } & \multicolumn{2}{|c|}{$\begin{array}{l}\text { Grain yield } \\
\left(\mathrm{kg} \mathrm{ha}^{-1}\right)\end{array}$} & \multicolumn{2}{|c|}{$\begin{array}{l}\text { Stover yield } \\
\left(\mathrm{kg} \mathrm{ha}^{-1}\right)\end{array}$} \\
\hline & 2012 & 2013 & 2012 & 2013 \\
\hline \multicolumn{5}{|l|}{ Preceding legumes in kharif } \\
\hline $\mathrm{C}_{1}$ : Sorghum preceded by Dhaincha & 2511 & 3024 & 5686 & 6127 \\
\hline $\begin{array}{l}\mathrm{C}_{2} \text { : Sorghum preceded by Greengram for } \\
\text { seed }\end{array}$ & 2446 & 2942 & 5487 & 6063 \\
\hline $\begin{array}{l}\mathrm{C}_{3} \text { : Sorghum preceded by Cowpea for } \\
\text { fodder }\end{array}$ & 2389 & 2947 & 5441 & 5999 \\
\hline $\mathrm{C}_{4}$ : Sorghum preceded by Fallow & 2409 & 2930 & 5367 & 6019 \\
\hline $\mathrm{SEm} \pm$ & 17.0 & 24.8 & 7.8 & 8.5 \\
\hline CD at $5 \%$ & 59 & 85 & 27 & 29 \\
\hline \multicolumn{5}{|l|}{ Irrigation schedules } \\
\hline $\mathrm{I}_{1}$ : Panicle initiation & 2338 & 2870 & 5311 & 5830 \\
\hline $\mathbf{I}_{2}:$ PI and booting & 2413 & 2929 & 5419 & 5953 \\
\hline$I_{3}:$ PI, booting and anthesis & 2477 & 2997 & 5570 & 6141 \\
\hline $\mathrm{I}_{4}: \mathrm{PI}$, booting, anthesis and milk stage & 2528 & 3047 & 5681 & 6286 \\
\hline S Em \pm & 13.4 & 6.4 & 36.1 & 37.5 \\
\hline CD at $5 \%$ & 46 & 22 & 124 & 131 \\
\hline \multicolumn{5}{|l|}{ Nitrogen $\left(\mathrm{kg} \mathrm{ha}^{-1}\right)$} \\
\hline $\mathbf{N}_{1}$ : No Nitrogen & 2039 & 2466 & 4863 & 5311 \\
\hline $\mathbf{N}_{2}: 30$ & 2380 & 2886 & 5305 & 5833 \\
\hline $\mathrm{N}_{3}: 60$ & 2650 & 3222 & 5708 & 6338 \\
\hline $\mathrm{N}_{4}: 90$ & 2686 & 3269 & 6104 & 6726 \\
\hline $\mathrm{S} \mathbf{E m} \pm$ & 54.5 & 57.3 & 131.5 & 140.0 \\
\hline CD at $5 \%$ & 188 & 199 & 457 & 484 \\
\hline \multicolumn{5}{|l|}{ Interaction } \\
\hline \multicolumn{5}{|l|}{ Kharif legumes $\times$ Irrigation } \\
\hline $\mathrm{S} \mathbf{E m} \pm$ & 46.0 & 64.4 & 49.5 & 54.5 \\
\hline CD at $5 \%$ & NS & NS & NS & NS \\
\hline \multicolumn{5}{|l|}{ Kharif legumes $\times$ Nitrogen } \\
\hline $\mathrm{S} \operatorname{Em} \pm$ & 190.9 & 204.4 & 456.9 & 484.4 \\
\hline CD at $5 \%$ & NS & NS & NS & NS \\
\hline \multicolumn{5}{|l|}{ Irrigation $\times$ Nitrogen } \\
\hline $\mathrm{SEm} \pm$ & 189.5 & 199.4 & 461.8 & 485.1 \\
\hline CD at $5 \%$ & NS & NS & NS & NS \\
\hline \multicolumn{5}{|l|}{ Kharif legumes $\times$ Irrigation $\times$ Nitrogen } \\
\hline $\mathrm{S} \operatorname{Em} \pm$ & 54.5 & 57.3 & 131.5 & 140.0 \\
\hline CD at $5 \%$ & NS & NS & NS & NS \\
\hline
\end{tabular}


In an earlier investigation, Pawar and Bhogi (2009) reported that the legumes differed in their influence on the relative performance of sorghum. Additional mean grain yield of 67, 133 and $184 \mathrm{~kg} \mathrm{ha}^{-1}$ was obtained due to 2,3 and 4 irrigations over 1. Similarly, the stover yield increased from $5311 \mathrm{~kg} \mathrm{ha}^{-1}$ due to irrigation at panicle initiation to $5419 \mathrm{~kg} \mathrm{ha}^{-1}$ by irrigating the crop at panicle initiation and boot leaf stage in the first year and from 5830 to $6286 \mathrm{~kg} \mathrm{ha}^{-1}$ in the second year. More quantity of 5570 and $6141 \mathrm{~kg} \mathrm{ha}^{-1}$ stover was obtained by irrigation at panicle initiation, boot leaf and anthesis stage during the two years. Maximum stover yield of 5681 and $6286 \mathrm{~kg} \mathrm{ha}^{-1}$ was obtained when the soil was not deprived of moisture stress at panicle initiation, boot leaf, anthesis and milk stage of grains.

It is inferred that the beneficial effects of growing dhaincha and its in situ incorporation at flowering in kharif as a preceding crop increased the production of sorghum grain and fodder vis-a-vis their nutrient value as food for man and fodder for cattle. The crop should be irrigated at the critical stages viz; panicle initiation, boot leaf, anthesis and milking stage of the grains to improve the vegetative growth, yield components and ultimately increasing their production.

\section{References}

Bhoi, P.G. and Jadhav, S.B. 1986. Studies on the effect of minimal irrigation and organic mulch on the yield and water use of rabi sorghum hybrids. $\mathrm{J}$ of Maharashtra Agril Univ. 11(3): 377378.

Fageria, N.K., Virupax, C., Baligar and Jones C.A., 2014. Growth and mineral nutrition of field crops. CRC Press, Boca Raton London, Newyork, Taylor and Francis Group, Sorghum. 11: 343 361.
Henadez, V.A.G., Manjarrez, S.P. and Mendoza, C.L.E. 1992. Drought-stress effect on dry matter production and distribution in sorghum plants. Sorghum News letter. 33:56.

Kamble, G.K. 1983. Studies on minimal irrigation and mulch on rabi sorghum [Sorghum bicolor (L.) Moench] CSH8R. M.Sc. thesis submitted to Mahatma Phule Krishi Vidyapeeth, Rahuri, India.

Kulakarni, K.R and Pandey, P.K. 1988. Annual legumes for food as green manure in rice based cropping systems. In: Sustainable agriculture-green manure in rice farming. Intl. Rice Res. Ins., Los Bonas, Leguna, Philippines. 289-299

Mahadkar, U.V and Saraf, C.S. 1988. Effect of various inputs on yield of urd bean and its residual effects on succeeding fodder sorghum. $\mathbf{J}$ of Maharashtra Agril Univ. 13(3): 293-295.

Mastronilli, M., Katerji, N and Rana, G. 1995. Water-efficiency and stress on grain sorghum at different reproductive stages. J of Agril Water Manage. 28(1): 19-22.

Mishra, J.S., Raut, M.S., Pushpendra Singh, R., Kalpana, Khubsad, V.S., Lokhande, O.G., Patel, Z.N., Thakur, N.S., Nemade, S.M., Spandana Bhat, Pramod Kumar, Kewalanand, 2011. Sorghum Agronomy: Kharif Report agm12: 1-16.

Mohiuddin, S.H and Mohammad Yaseen. 1973. A note on the effect of moisturestress on the yield components of sorghum 'CSH-1'. Indian J. of Agr. 18(1): 96-97.

Patil, N.D., Umrani, N.K., Shende, S.A., Manke, B.S., Kale, S.P and Shingte, A.K. 1981. Improved crop production technology for drought-prone areas of Maharashtra. Technical bulletin of Dry Farming Research Station, Solapur, India. Pp: 55-58, 96. 
Pawar, A.D and Bhogi, R.S. 2009. Effect of green manure and its incorporation methods in rabi sorghum cropping system. Annals of Plant Physiology. 23(2): 162-164.

Ramshe, D.G., Mane, S.S and Pol, P.S. 1985. Irrigation studies on rabi (winter) sorghum. Current Res. Rep. 1(1): 52-55.
Refay, Y.A. 1989. The influence of variable amounts of irrigation water and nitrogen fertilizer and their interaction on the development, growth and nitrogen uptake of grain sorghum. Dissertation Abstract in International B. Sciences and Engineering. 50(5):1701B.

\section{How to cite this article:}

Balazzii Naaiik, R.V.T., J.S. Mishra and Madhavi, A. 2018. Performance of Rabi Sorghum as Influenced by Preceding Legumes, Nitrogen Levels and Irrigation Schedules. Int.J.Curr.Microbiol.App.Sci. 7(12): 3621-3628. doi: https://doi.org/10.20546/ijcmas.2018.712.410 